\title{
Brief Analysis of Education Industrialization under China's Market Economy
}

\author{
Gaoshen Li \\ Scientific Research Office of Academic \\ Huanghe Science and Technology College \\ Zhengzhou, China 450006
}

\begin{abstract}
The definition of the education industrialization is the education are considered as an industry, the school is considered as a company. The market economy mechanism and rule should be transplanted into the whole education to allocate the education resource by market mechanism. The school should put the profits maximization as the target, by autonomous operation and independent accounting. In this way, the relationship between education and economy turn into a kind of direct and instant relationship, so the education itself become into a kind of economy activity. Thus, education industrialization will equal the education's economic attributes to its essential attributes, and the education will be dissimulated during its industrialization.
\end{abstract}

Keywords-market economy; education and economy; education industrialization

\section{INTRODUCTION}

When human steps into the 21st century, knowledge makes the brilliant contribution to the global economy development. Thus, the education as the most important base for knowledge is becoming a treasure, deeply attracted by the world wide attention. So, some people considered that only to bring the education into the economy category and to develop the education as economy rule, then problem of economy development could be truly solved. The education is given an unprecedented economic important task, to stimulate the consumption and investment of education, to fuel economic growth. And enlarging the educational scale can help to release the pressure of employment; and the conflicts between educational investment and demands will be solved by the market. So "education industrialization" challenge to the school education as a strong educational ideological trend.

It is undeniable that there has an internal relationship for the development of education and economy. However, when we are paying attention to the attributes of education, we should review its history. If the deviated educational attributes starts to generalize the social function of education, the development of society and human will be destined to suffer a very rough experience, such as the 10 years "cultural revolution" political movement finally turn into a tragedy. Also might as well, in present "economization society", why people feel hard to find a favorable spiritual life? I never denied the economic development function of education, also has no any intention to blame the reference from the market mechanism for our education development. Here I just express my personal opinions for the education industrialization with a humanistic care.

\section{EDUCATION Dissimilation FOR EdUCATING PEOPLE DURING THE EDUCATION INDUSTRIALIZATION}

People educating is the essential rules of education. And to cultivate people with perfect personality is the aim of education. Certainly, the people in education is based on the person from the social life, The education can realize its various social function by people. So we can understand that The definition of the education industrialization is the education are considered as an industry, the school is considered as a company. The market economy mechanism and rule should be transplanted into the whole education to allocate the education resource by market mechanism. The school should put the profits maximization as the target, by autonomous operation and independent accounting. In this way, the relationship between education and economy turn into a kind of direct and instant relationship, so the education itself become into a kind of economy activity. Thus, education industrialization will equal the education's economic attributes to its essential attributes, and the education will be dissimulated during its industrialization.

First of all, the performance of the education dissimilation is the people's dissimilation. Originally, in the education activity, the student is the carrier of the influence by education, and for other factors as teachers, education measures exist for the students, so students is the real "master" of the education. However, as for "education industrialization", this relationship has been completely reversed, the students become the object of the education industry processing, and the students are the "raw materials" of a teacher. Then teachers make his students into kind of "standard component" according to the market model and economic structure. Students lost their main position and independence consciousness completely, from human to "nonhuman", became a kind of container without any ideas, even become a "product" that can increase in value. So, if the teacher can really become into a "person"? No, the teacher is as a "nonhuman" also in the "education industrialization". He is just the school's employee and the work for production, which is can not have independent consciousness. So he only 
strictly to teach according to the requirements of social economy, all of his activities are no longer to develop the wisdom and personality of students, but like try to achieve the pass ration of some kind of "product". As Marx said: "why a teacher is called as the production workers, not because he trained his student's mind, but because he brought a lot of wealth for his school governors." Teacher is just like a tool even a teaching machine for realizing the profit maximization, teaching. The whole "Industrialization" educating process is reflecting that "the product value is going up, but the people quality is going down".

Secondly, the education dissimilation manifests itself into the school's dissimilation. People are the object for education. The education basic function is people cultivating. Any education revolution only need to strength this function rather than weaken it. However, when the education starts to tend to kind of tools, its cultivated people of education would only be the economic man, politics or other one-side developed man. "The education industrialization" put all the educating activities into the track of market economy, and turns the school into an economic entity. In this way, the school is far from education, the education is far from the people. Once the school forgets its object, its object also will forget the school. So the phenomenon is resulted, for instance, "school is prospect, the education become decline". So if the school is far from its basic function as cultivating people, then it will not to be as an education organization.

In China, the education industrialization does not become into the fact, but in the china market economy trends, the market mechanism are applied to the education by some people, such as the fake diploma or diploma exchanged by money and so on. Although the market competition and laws can remit such problems, need the very high price and the impaired host will be the young generation and the society.

\section{III. "EDUCATION INDUSTRIALIZATION" INTENSIFY THE TECHNOLOGY UTILITY, WEAKEN THE LITERARY ACCOMPLISHMENT, AND TO IMPEDE THE DEVELOPMENT OF} PEOPLE AND SOCIETY

The value orientation is kind of isolation among the education, people and society. Now the better relationship between people and society become the basic orientation for education. It will be realistic requirements for building and integrating the system of humanity and utility for people and society development. It is natural that people always rely on the materials and expects more and more possession. Motivated by profit, obtaining more knowledge has become the core for the modern education. Meanwhile, people start to forget to develop the spiritual civilization and itself. The one-side society development and the people's lost in the education remind us that the china education need to do the introspection for its humanistic significance.

Actually, before the education industrialization starts, the china education was affiliated to the economy. It is the important purpose that for the china's education as to develop the economy and obtain the economic profits. In order to follow the requirements of market economy, the school pays more attention to the technology lessons rather than the basic theory learning and researching. The most popular major for students are the majors which easily can help earn a lot of money. And the majors for history, literature are desolated by students. Now the instrumental reason supports the whole education, the education no longer care about the meaning of the man and living. When the instrumental value captures the surviving space for humanistic value, the people can not own the rich cultural quality and spiritual life. The education industrialization restricts the relationship between people and society to the single area of economy. The technology will occupy the dominant position and the humanistic education is marginalized. So the education industrialization makes people cant feel the complete meaning of life and living and turn into an "economic man".

Social progress is a unified whole process of the evolution of people and objects. Economic development is certainly a sign of social progress. If the economic development was at the expense of becoming the human for people, the social progress is bound to be deformed. Facts have proved this point, since modern times, the education emphasized on the social and economic development functions, then the man became into the one side developed man as the education and economy's intermediaries and tools.

Under the motivation of scientific and technological revolution, human created a remarkable material civilization, but at the same time, also accumulate the various contradictions and problems: such as the financial crisis, the wealth gap, environmental degradation, ecological imbalance, the energy crisis, the arms race, nuclear war crisis and social injustice and so on. These problems directly threat to the continued existence and development of human beings. It is not localized but global problem, which is involved with the economic, political, moral and other fields. The cruel reality has told us that to improve the quality of people is the key to solving social problems. In the half of the 1970s, the "endogenous human-centered development" theories and models were proposed by UNESCO. The theory is "the development of economic substance is exogenous, the progress of people own development and cultural values is endogenous, and to emphasis that people is the promoter and purpose for the development."

Education should be based on the responsibility for people cultivation, and to promote social progress by this responsibility. However, the "education industry" is marginalizing the human development, and taking the economic value as its center. When education and economic development is separated from the human values and goals, the human society will lose its direction of progress, which inevitably will push human into the disaster.

In the development of human society, we must comprehensively and scientifically grasp the status and role of education. The education is neither a consumable career nor a means of human resource development, even not simply equated with economic activity, we should put the human development as a fundamental goal of education and social progress, and we should treat the education from the angle of the sustainable development of society. 
IV. THE EDUCATION INDUSTRIALIZATION INTENSIFY THE UNFAIRNESS OF EDUCATION, DEVIATING FROM THE HUMAN PURSUITS OF EQUAL RIGHTS FOR BEING EDUCATED

Education has always been an important need for human survival and development. "Declaration on Education for All" in 1990 by the World Conference on Education explicitly declared: "Everyone - whether he is a child, youth or adult - should be able to have the opportunity be educated and got benefit from education designed to meet their basic learning needs."Pursuit of receiving a suitable education for all becomes the common goal of the education development all over the world. As for the social and individual factors, education is a kind of developmental resources. Since it is a resource, there exists a problem for distribution. So the education fairness becomes one of the focuses on education development.

Educational equity is an important part of social fairness, also includes the meaning of "justice" and "equality" As for the allocation of educational resources, it is necessary to respect the public opinion, and to meet the people's demand for education as much as possible. Also should consider the ability of educational resources allocation for the present period. When it is not sufficient to guarantee to all persons subject to high quality and high levels of education, it is necessary to carry out differences distribution of educational opportunities. It should be noted that forbidden artificially expanding the difference, otherwise there will emerge or intensify the education unfairness.

Education is part of the tertiary industry category, but it provides a non-physical form of "public goods to be". "Education service is jointly provided by the government and the market, planning and market mechanisms function together." In addition, education is valuable to society and individual's development, which is to say in this way there can get both the economic and non-economic benefits. For the reasons above two aspects, the education costs should be shared by social and individual, but due to the education is a social public issue, therefore, the state and the government should be mainly responsible for the cost of education. The individual to be educated should be responsible for the appropriate portion of it, so that the distribution of educational resources would be more close to educational equity.

For a long time, there exists unreasonable phenomenon for our country's educational resources allocation, due to factors such as governmental policy bias and different region's economic development, such as the difference between urban and rural areas, different regions, and different social ranks. Presently the educational unfairness phenomenon has caused widespread concern of all sectors of the community.

"Education Industrialization" disregards the education's double-sided value orientation to social and individual, just one-side emphasis on market allocation of educational resources. It will intensify the educational to charge the tuition fees based on the cost and profits by the profit-driven lever. Since the big reform and opening up, although the living conditions of residents generally been greatly improved, at the same time is gradually the gap between rich and poor are gradually enlarged. it is an indisputable fact. According to the investigation of People's University professor Li Qiang, the Gini coefficient of urban and rural residents average household income, it is 0.4577 for 1 year, which beyond 0.4 the internationally recognized warning level. "By another statistics, presently China still have 5000-6000 million rural poor people and tens of millions laid-off workers. This reflects our country's wealth gap is relatively large. Therefore, when we conduct the education reform process, we must consider people's ability and endurance for education of different the income levels. If education was regarded as the merchandise, in accordance with market principles of supply and demand, otherwise, the competition of educational opportunities would become a competition of economic income. The people who have money have more educational opportunities and rights. Some people think that our banks have six trillion yuan resident deposits, which hears like a huge purchasing power of education. But as we all know, the deposit $80 \%$ is owned by $20 \%$ people. Under the situation of the huge difference between the rich and the poor, if the school charges the high education fees, only a small number people can afford for the college study. (according to some people's statistics, if implemented the industrialization of education, then the annual fees for student higher education will be up to five, six million), especially the poor people's right for higher education opportunities definitely to be denied. Due to the right for getting higher education is deprived, thus the poor people also devoid the desire of the poor to primary and secondary education. In this case, our education will no longer to be the public good and become a monopoly of a few rich people. There is no doubt that this is not the needs for China's social modernization.

"The primary goal of the educational system should be to reduce the vulnerable level of the children from the marginalized and disadvantaged ranks in the society. So as to break the vicious cycle of poverty and exclusion phenomenon, "education is a method for mankind move towards happiness and freedom. Our country and individuals should make the efforts for achieving the ideal of the educational fairness. We should not distort the essence of education and industrialize the education on account of a temporary economic difficulties and education fund intention. Educational equity has become the basic orientation of the value of modern education all over the world, just because education has become basic human rights of citizens in modern society. It can effectively improve people's living conditions and promote social equity.

\section{CONCLUSIONS}

It is necessary that to adapt to the era development and to use the market economy mechanisms to regulate the education activities as presently the education is very closely involved with the economic life. The concept of "Education industrialization" is originated from the intention for rescue the economic plight by education. In fact, the education industrialization is the misunderstanding for the essence of education and it is also a one-sided grasp of the education 
multinational properties. If we use this to guide educational practice, it will be bound to lead the confusion of the education order, which will really result into an "inhuman" way for the education. Presently human subjectivity is highly praised, so "education industrialization" is the contrary to the pursuit of contemporary education's humanistic value and meaning.

\section{REFERENCES}

[1] Marx: "Das Kapital" book 1, "Marx and Engels theory of education"(A), People's Education Press, 1986 enlarged edition。

[2] UNESCO international education development committee: "Learn To Be" [M], Science and Education Press, 1996 Published

[3] Du Shizhong: "scientific and humanistic education" [M], Central China Normal University Press, 1998 Published 。

[4] UNESCO: "Education - wealth inside it"[M], Science and Education Press, 1996 Published。

[5] Chen Guisheng: "Principles of Education" (M), East China Normal University Press, 2000Published。 